\title{
Filtration and fertilisation effects of the bivalves Mytilus edulis and Magallana gigas on the kelp Saccharina latissima in tank culture
}

\author{
Matthew S. Hargrave ${ }^{1,2}$ (D) Anothai Ekelund ${ }^{1} \cdot$ Göran M. Nylund ${ }^{1,2}$ (D) $\cdot$ Henrik Pavia $^{1,2}$
}

Received: 5 February 2021 / Revised and accepted: 21 June 2021 / Published online: 23 July 2021

(c) The Author(s) 2021

\begin{abstract}
Biofouling by opportunistic epiphytes is a major concern in seaweed aquaculture. Colonisation of fouling organisms contributes to a reduction in algal performance as well as a lower quality crop. Further, epiphyte removal techniques often increase maintenance costs of cultivation systems. There have been a variety of methods to mitigate fouling in tank cultivations of seaweed, including the use of biological controls. Here, we present the use of filter feeding bivalves, the blue mussel (Mytilus edulis) and Pacific oyster (Magallana gigas), as a novel biofilter that also serves as a source of dissolved inorganic nitrogen in tank cultivations of the sugar kelp, Saccharina latissima. We observed significant reductions of fouling epiphytes on seaweed blades of around $50 \%$ by bivalve filtration, significant elevations of ammonium $\left(\mathrm{NH}_{4}{ }^{+}\right)$and phosphate $\left(\mathrm{PO}_{4}{ }^{3-}\right)$ by bivalves and alterations to kelp tissue quality when co-cultivated with bivalves rather than supplied with ambient seawater. Stable isotope ratios and seawater chlorophyll $a$ concentrations provided evidence for bivalve biofiltration and the incorporation of their by-products into kelp tissue.
\end{abstract}

Keywords Epiphyte $\cdot$ Biofouling $\cdot$ Co-cultivation $\cdot$ Biofilter $\cdot$ IMTA $\cdot$ Aquaculture

\section{Introduction}

The growth of epiphytic organisms on crops has long been a problem in aquaculture (Dürr and Watson 2010). In seaweed cultivation, the presence of fouling organisms impacts the quality of the seaweed which, in severe cases, can render a crop unfit for human consumption (Rolin et al., 2017). Furthermore, fouling species can have strong negative effects on the access of both light and nutrients to cultivated seaweeds, thereby reducing their growth and tissue quality (Veeragurunathan et al., 2015; Bannister et al., 2019), while herbivorous fouling species can cause decreases in biomass and crop yields (Buschmann et al., 2001). Epiphyte mitigation techniques may result in increased maintenance costs (Kim et al., 2017) and can be very labour intensive (Hurtado et al., 2006). To mitigate biofouling in field cultivations, harvesting is often conducted early in the year, before the spawning of

Matthew S. Hargrave

matthew.hargrave@gu.se

1 Department of Marine Sciences -Tjärnö Marine Laboratory, University of Gothenburg, 45296 Strömstad, SE, Sweden

2 Swedish Mariculture Research Centre (SWEMARC), Gothenburg, Sweden fouling organisms, resulting in a shortened seaweed culture period and yield (Park and Hwang 2012). Other biofouling mitigation efforts have been made, such as deploying gear at specific times to avoid coinciding with natural spawning of biofouling species (Chopin et al., 2001) and moving gear to more exposed areas to reduce epiphytic settlement (Peteiro and Freire 2013). As an alternative or complement to field cultivations, tank-based cultivation of seaweed has been employed, where a higher level of control over environmental factors can be achieved. However, the issue of biofouling is also problematic in tank cultivation and has been addressed by a number of studies. Methods to mitigate biofouling in tank cultivations have included mechanical methods (Edding et al., 1987; Lignell and Pedersén 1989; Pickering et al., 1993), environmental manipulation (Rueness and Fredriksen 1989; Friedlander 1992; Haglund 1994; Kim et al., 2017), chemical control (Ugarte and Santelices 1992; Gledhill et al., 1998) and biological control (Shacklock and Doyle 1983; Smit et al., 2003). Despite a history of research utilising a wide array of different methods, biofouling on seaweed crops remains a significant problem. As summarised by Bannister et al., (2019), 'Aquaculture may help feed the world into the future, but biofouling stands out as a clear barrier that needs to be overcome first'. 
Alongside biofouling pressure, nutrient limitation has been identified as a second major issue in macroalgal cultivation (Wheeler and North 1981). In most natural environments, nitrogen $(\mathrm{N})$ and phosphorus $(\mathrm{P})$ have been identified as the macronutrients that most restrain algal growth (Harrison and Hurd 2001). As such, the seasonal variation of this limiting factor has great influence on seaweed yields (Handå et al., 2013; Peteiro and Freire 2013). Further, the assimilation rate of ammonium, and therefore kelp growth, is dependent on external nutrient concentration, where the rate may be limiting in the case of low ambient concentrations (Taylor and Rees 1999), but enhanced by nutrient addition, such as by IMTA. In systems subject to natural nitrogen dynamics, the marked decline in kelp growth during spring and summer is due to declines in ambient nitrogen availability and the depletion of internal nitrogen stores after rapid growth (Chapman and Craigie 1977). In temperate areas, $N$ and $P$ generally peak during autumn and winter, and are most depleted during spring and summer (Harrison and Hurd 2001). Seaweed farmers have no control over these seasonal variations in nutrients but can apply various methods to manipulate local nutrient conditions. One such method is to apply slow dissolving fertiliser within the farm to provide a relatively steady source of nutrients (Ogawa and Fujita 1997; Dean 1998). Another option is the employment of co-cultivation systems, whereby seaweed nutrient supply can be enhanced by growing seaweeds in proximity to organisms that supply high levels of these limiting nutrients, such as finfish cultivations (Troell et al., 1997) or intensive bivalve cultivations (Ajjabi et al., 2018).

The clearance rate of intensive bivalve cultivations, for example rafts of the blue mussel (Mytilus edulis), has been reported to remove a large proportion, up to $80 \%$, of phytoplankton from the surrounding water (Petersen et al., 2008; Cranford et al., 2014) as well as to have a total filtration capacity of all particles of suitable size by up to 41\% (Wildish and Miyares 1990). This depletion of phytoplankton by bivalve cultivations has been observed on the scale of kilometres around farms (Grant et al., 2008). For this reason, filter feeding bivalves are commonly employed in integrated multi-trophic aquaculture (IMTA) systems in efforts to capture excess particulate waste produced by fish farms (Soto 2009).

However, while blue mussels and other filter feeding bivalves have been implemented as extractive species, they also produce their own metabolic wastes (Dame and Dankers 1988). Of which, the dissolved fraction is primarily in the form of dissolved inorganic nitrogen (DIN), particularly ammonium $\left(\mathrm{NH}_{4}{ }^{+}\right)$, and dissolved inorganic phosphorus (DIP) in the form of phosphate $\left(\mathrm{PO}_{4}{ }^{3-}\right)$ (Jansen 2012). This has been observed in the natural environment, where large aggregations of wild mussels have been identified as producers of DIN, elevating nitrogen concentrations locally around bivalve beds (Dame et al., 1989; Aquilino et al., 2009). Similarly, elevated DIN has been observed around commercial bivalve farms (Haines 1975; Langton et al., 1977; Mao et al., 2009), and often on the scale of entire bays and enclosed water bodies where bivalve aquaculture is intensive (Ajjabi et al., 2018). The local production of DIN by bivalves, both farmed and wild, suggests that there is potential for incorporation of seaweeds into and around bivalve cultures to capitalise on this local nutrient loading, as explored by Freitas et al., (2016). While the combined cultivation of kelp and mussels has been tentatively explored in open water; to date, no studies have examined potential for this co-culture in tank cultivation.

The aim of this study was to investigate the effects of integrated co-cultivation of a commercially important macroalga, Saccharina latissima, and bivalves, Mytilus edulis and Magallana gigas, in tank culture. We hypothesised that the presence of bivalves would produce a biofiltration effect resulting in a reduction in epiphytic fouling organisms on seaweed tissues. We also hypothesised that the presence of bivalves would significantly increase the DIN and DIP concentrations within the cultivation system, resulting in alterations to kelp growth and internal nutrient partitioning.

\section{Methodology}

\section{Study organisms and growth measurements}

\section{Saccharina latissima}

One-year-old adult sporophytes of Saccharina latissima $(n=180)$ were selected from high-density indoor tank cultivations at the Tjärnö Marine Laboratory, based on a size range $(350-500 \mathrm{~mm})$. This ensured that all kelps were of the same age and in virtually identical condition. Saccharina latissima individuals were placed in experimental aquaria $(\mathrm{n}=18$ aquaria, $\mathrm{n}=10$ individuals per aquarium) 1 week prior to the addition of bivalves and commencement of the experiment. After 1 week of acclimation time to the experimental conditions, measures of kelp size were taken: total length, width at widest point and wet weight. Hole punches (5-mm diameter) were made at $50 \mathrm{~mm}$ and $100 \mathrm{~mm}$ from the stipe-meristem junction according to the method of Parke (1948) for quantification of growth rate. These measures were used to calculate total elongation, relative growth rate (RGR), and substantiality index (SI) at the end of the experimental duration.

$$
\begin{gathered}
\text { Total elongation }\left(m^{-1}\right)=L_{1}-L_{0} \\
R G R\left(m^{-1 a y} \text { day }^{-1}\right)=L_{1}-L_{0} / T \\
\operatorname{SI}\left(\mathrm{mg} \mathrm{mm}^{-2}\right)=W W / L_{1} x W_{1}
\end{gathered}
$$

where $L_{0}$ is the holepunch distance from stipe-meristem junction at the beginning of the experiment, $L_{l}$ is the 
holepunch distance from stipe-meristem junction at the end of the experiment, $T$ is the number of days, $W W$ is the wet weight of the blade and $W_{1}$ is the width at the end of the experiment.

Measures were repeated at weekly intervals for the 12-week experimental duration. Any epiphytes were diligently removed at the end of the experiment, whereafter the kelp individuals were frozen for subsequent analysis of elemental composition. Prior to freezing, the individuals were photographed to quantify epiphyte coverage. During the experiment, we observed that some individuals started to develop fertile tissue (sorus). To investigate possible treatment effects on the development of sorus, all kelps were visually assessed for the presence or absence of fertile sorus tissue from photographs.

\section{Mytilus edulis and Magallana gigas}

Mytilus edulis and Magallana gigas were collected from shallow, muddy embayments on Tjärnö and Saltö ( $58^{\circ} 52^{\prime}$ $37.3^{\prime \prime} \mathrm{N}, 11^{\circ} 08^{\prime} 11.2^{\prime \prime} \mathrm{E}$ ) within a size range of $50-70 \mathrm{~mm}$ and $70-90 \mathrm{~mm}$ (from umbone to longest point) respectively. Replicates of 36 individuals ( $n=6$ per treatment) were transferred into mesh bags, or 'socks', and hung inside experimental pipes. Bivalve density was based on the filtration capacity of the bivalves, where filtration rates of up to 2.7-3 $\mathrm{L} \mathrm{h}^{-1}$ have been observed in M. edulis (Lindahl et al., 2005; Aure et al., 2007) and between 1 and $12 \mathrm{~L} \mathrm{~h}^{-1}$ in M. gigas (Troost 2010), with the assumption that all water, at a flow speed of $90 \mathrm{~L} \mathrm{~h}^{-1}$, would theoretically be filtered in each treatment pipe. Bivalve mortality was assessed at the end of the experimental duration.

\section{Experimental system}

An outdoor, semi-enclosed flow-through mesocosm system was designed (Fig. 1A -C). Unfiltered sub-surface water (1.5 $\mathrm{m}$ depth) was pumped into a large, elevated header tank with an overflow pipe located $2 \mathrm{~m}$ from the base. Overflowing water ensured a constant volume in the header tank, and thus a constant supply to the experimental tanks. Water was supplied to 18 individual $1-\mathrm{m}$ vertical pipes $(\mathrm{n}=18$ total, $\mathrm{n}=6$ containing $M$. edulis, $\mathrm{n}=6$ containing $M$. gigas, $\mathrm{n}=6$ control (empty)) via gravity from the header tank at a rate of 90-100 $\mathrm{L} \mathrm{h}^{-1}$. Water flowed into the base of the bivalve pipes through thin 4-mm aperture silicon tubing under pressure produced by gravity from the elevated header tank. The supplied water then flowed through the bivalves before flowing from the tops of the pipes into aquaria $(54 \mathrm{~L})$ containing ten individuals of $S$. latissima $(\mathrm{n}=18)$. Water overflowed from the seaweed aquaria and out of the system. The entire system (pipes and aquaria) was covered in hessian cloth to reduce light intensity. Aquaria were aerated individually and were cooled by external circulation of deep seawater pumped from $40 \mathrm{~m}$. Light (lumens) and temperature $\left({ }^{\circ} \mathrm{C}\right)$ were monitored in seaweed aquaria and bivalve pipes with submersible loggers ('HOBO' temperature pendant logger, Onset Comp. Corp., USA) at 30-min intervals for the duration of the experiment. The average temperature in kelp aquaria across the experimental duration was $13.7 \pm 2.9{ }^{\circ} \mathrm{C}$ while the mean light intensity during daylight hours was
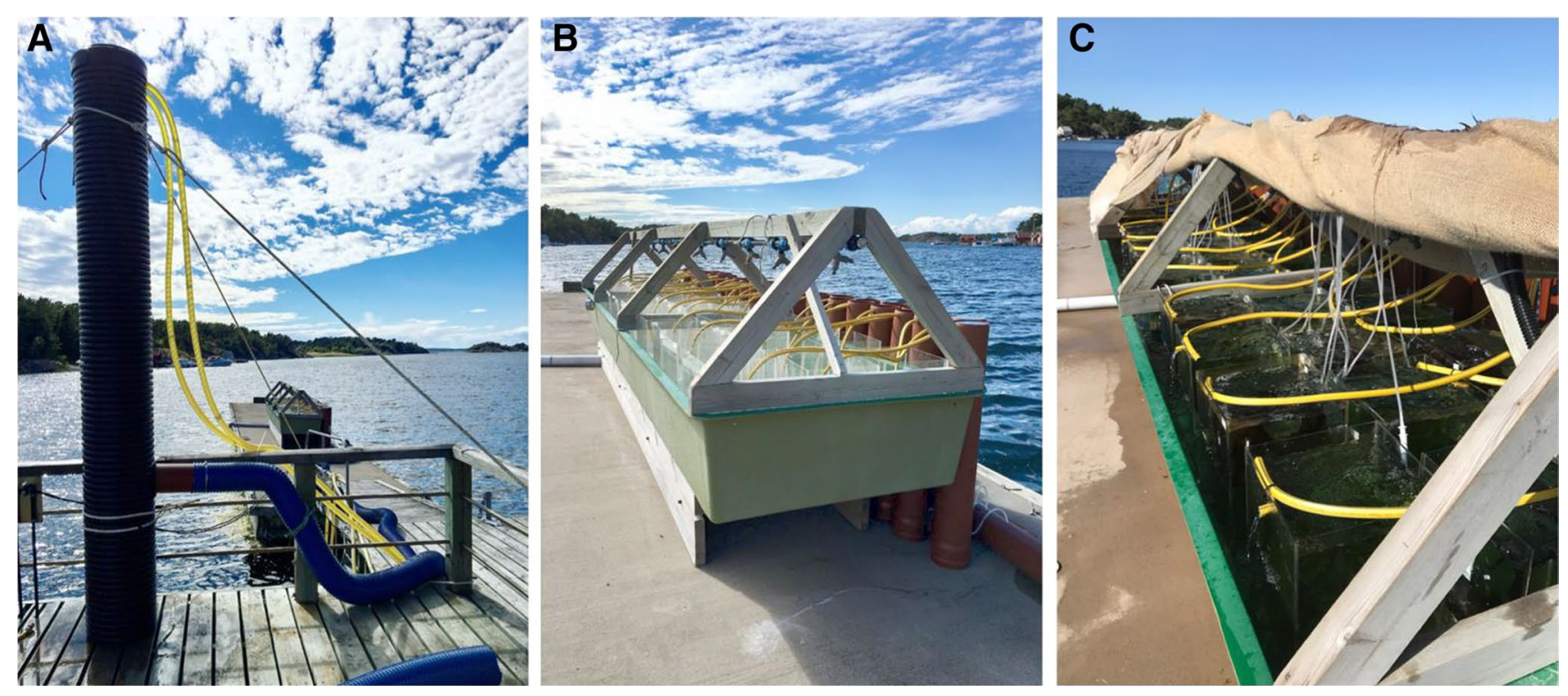

Fig. 1 Photographs showing the experimental system: (A) elevated header tank supplying surface water to experimental system, (B) experimental system showing kelp aquaria and bivalve pipes, $(\mathbf{C})$ experiment in progress 
$218.4 \pm 380$ lumens (mean \pm SD). The small amount of variation in water temperature indicates that the circulation of cold, deep water around the experimental aquaria provided a good buffer against temperature fluctuation.

\section{Dissolved inorganic nitrogen and phosphorus}

Water samples for DIN and DIP analysis were taken weekly across a random subsample of bivalve pipes $(n=6$ per treatment, $\mathrm{n}=18$ total) and their corresponding seaweed aquaria. Thus, DIN and DIP were sampled before the bivalves, after the bivalve treatment, and after the seaweed treatment.

Fifteen millilitre of water was collected from each point and filtered through $45-\mu \mathrm{m}$ Whatman GF/C filters using a $25-\mathrm{mL}$ plastic syringe. The filter was then discarded and water samples in vials were immediately frozen. Early samples were analysed using a SEAL QuAAtro analyser with XY-3 sampler (SEAL analytical, Norderstedt, Germany) for concentrations of nitrite $\left(\mathrm{NO}_{2}{ }^{-}\right)$, nitrate $\left(\mathrm{NO}_{3}{ }^{-}\right)$, ammonium $\left(\mathrm{NH}_{4}{ }^{+}\right)$and phosphate $\left(\mathrm{PO}_{4}{ }^{3-}\right)$. However, early water samples only revealed production of $\mathrm{NH}_{4}{ }^{+}$but no significant elevation of $\mathrm{NO}_{2}{ }^{-}$or $\mathrm{NO}_{3}{ }^{-}$, as such $\mathrm{NO}_{2}{ }^{-}$and $\mathrm{NO}_{3}{ }^{-}$sampling was reduced in later sampling weeks. DIN and DIP samples represented a brief weekly snapshot rather than a continuous measure. As such, weekly data was pooled and treated as a mean value of the 12-week experimental duration.

\section{Chlorophyll a}

Chlorophyll $a$ concentration in seawater after bivalve treatments was sampled weekly as a measure of phytoplankton abundance and filtration by bivalves. $0.5 \mathrm{~L}$ of bivalve outflow water was randomly sampled $(n=6$ per treatment, $\mathrm{n}=18$ total). Water was filtered through $45-\mu \mathrm{m}$ Whatman GF/C filters using a pressure-assisted filter array. The filtrate was discarded and the filter was ground, placed in $15-\mathrm{mL}$ Falcon tubes with $10 \mathrm{~mL}$ acetone $(90 \%)$, vigorously vortexed, and refrigerated at $5^{\circ} \mathrm{C}$ for $24 \mathrm{~h}$ for extraction of chlorophyll $a$. The tubes were vortexed again followed by centrifugation at $3000 \mathrm{rpm}$ for $10 \mathrm{~min}$. Sample absorption was measured at 665 and $750 \mathrm{~nm}$, with $90 \%$ acetone as a blank. Chlorophyll $a$ content was calculated as described by Boyd (1979):

Chlorophyll a $\left(\mu \mathrm{g} \mathrm{L}^{-1}\right)=11.9\left(A_{665}-A_{750}\right) \mathrm{V} / L / S$

where $A_{665}$ is the absorbance at $665 \mathrm{~nm}, A_{750}$ is the absorbance at $750 \mathrm{~nm}, \mathrm{~V}$ is the volume of acetone $(\mathrm{mL}), \mathrm{L}$ is the volume of water sample filtered $(\mathrm{mL})$ and $\mathrm{S}$ is the length of light path $(\mathrm{cm})$.

As with the case of DIN and DIP, chlorophyll $a$ samples represent a brief weekly snapshot of phytoplankton presence and filtration by bivalves rather than a continuous measure.
As such, weekly data was pooled and treated as a mean value of the 12-week experimental duration.

\section{Epiphyte coverage}

At the endpoint of the experiment, all kelp individuals were photographed (Canon D1100) against a light board. The area between the two holepunches was chosen as the area for the epiphyte counts, since this tissue was known to be the same age in all individuals, and to have had the same exposure to the experimental conditions. Moreover, this apical region has been identified as the portion of the kelp thallus that is most susceptible to epiphyte colonisation (Ballantine 1979). A maximal area $\left(\mathrm{cm}^{2}\right)$ between the punches was calculated using ImageJ software, and all epiphytes within the area were counted manually for half of the seaweeds ( $n=5$ per treatment, $n=90$ total). The prevalence of epiphytes was calculated as number $\mathrm{cm}^{-2}$.

\section{Kelp elemental analysis}

At the end of the experiment, seaweed individuals were frozen, freeze-dried and ground into a fine powder. A random subsample of kelps ( $n=5$ per aquarium) were selected for elemental analysis via isotope radio mass spectrometry (EA-IRMS). Ten milligramme of ground kelp tissue was weighed into tin capsules for analysis. The five subsamples per aquarium were then calculated as a mean for each true replicate $(n=6$ per treatment, $n=12$ total). Carbon and nitrogen contents were investigated to explore how shifts in nitrogen regime may alter kelp composition, while stable isotope ratios were measured to explore to what extent kelps in either treatment were utilising different nitrogen pools. Carbon and nitrogen contents and stable isotope values were quantified with an elemental analyser (ANCA-GSL, Sercon Ltd., UK) coupled to an isotope ratio mass spectrometer (20-22, Sercon Ltd., UK).

\section{Statistical analysis}

Analysis was undertaken by one-way ANOVA using the linear model function in R-Studio. To test for a nutrient filtration effect by $S$. latissima, paired t-tests between bivalve outflow water and S. latissima outflow water were performed for each of the four nutrients at each of the three treatment levels, M. edulis, M. gigas and control. Data were examined for homogeneity of variance prior to analysis and chlorophyll $a$ as well as nutrient data were log transformed prior to statistical testing. Significant interactions in the one-way ANOVA were further examined by Student-Neuman-Keuls (SNK) stepwise differences tests. Figures were produced in R-Studio using the 'ggplot2' 
package. Sorus formation based on count data was analysed using Kruskal-Wallis rank-sum test followed by group comparisons using the Dunn test.

\section{Results}

\section{Dissolved nitrogen and phosphate}

$\mathrm{NO}_{2}{ }^{-}$levels were consistently low in control pipes supplied with ambient seawater, $0.13 \pm 0.007 \mu \mathrm{M}($ mean $\pm \mathrm{SE})$, but were significantly enhanced in $M$. edulis pipes, $0.26 \pm 0.09 \mu \mathrm{M}$ (mean $\pm \mathrm{SE})$, whereas $\mathrm{NO}_{2}{ }^{-}$levels in $M$. gigas and control pipes did not significantly differ (Table 1; Fig. 2A). There was no detectable reduction in nitrite levels in outflow from seaweed aquaria in $M$. edulis treatments $(\mathrm{t}=1.27, \mathrm{df}=5, \mathrm{P}=0.26)$ or in $M$. gigas treatments $(\mathrm{t}=2.49$, $\mathrm{df}=5, \mathrm{P}=0.055)$. However, in control tanks, S. latissima significantly reduced $\mathrm{NO}_{2}{ }^{-}$levels from $0.13 \pm 0.007$ to $0.10 \pm 0.015 \mu \mathrm{M}($ mean $\pm \mathrm{SE})(\mathrm{t}=2.86, \mathrm{df}=5, \mathrm{P}=0.035)$ (Table 1, Fig. 2A).

$\mathrm{NO}_{3}{ }^{-}$levels, $0.96 \pm 0.07 \mu \mathrm{M}$ (mean $\left.\pm \mathrm{SE}\right)$, were not seen to vary from ambient seawater inflow across any stage of the experimental system nor between the bivalve and seaweed stages of control treatments $(\mathrm{t}=0.110, \mathrm{df}=5, \mathrm{P}=0.92), M$. gigas treatments $(\mathrm{t}=-0.279, \mathrm{df}=5, \mathrm{P}=0.79)$, or M. edulis treatments $(\mathrm{t}=0.187$, $\mathrm{df}=5, \mathrm{P}=0.86)$ (Table 1, Fig. 2B).

Both blue mussels and oysters significantly enhanced ammonium levels in comparison to control treatments, from $4.4 \pm 0.18$ to $5.5 \pm 0.16 \mu \mathrm{M}$ (mean $\pm \mathrm{SE}$ ) for blue mussels and $4.9 \pm 0.12 \mu \mathrm{M}$ for oysters. Thus, blue mussels and oysters provided a 12-week experimental average elevation of $1.1 \mu \mathrm{M}$ and $0.99 \mu \mathrm{M}$, respectively. The greatest weekly elevation of $\mathrm{NH}_{4}{ }^{+}$was observed for blue mussels $(9.93 \mu \mathrm{M}$ compared to $3.83 \mu \mathrm{M}$ in controls), whereas the weekly elevation by oysters was generally lower (9.03 $\mu \mathrm{M}$ maximum). $\mathrm{NH}_{4}{ }^{+}$levels were significantly reduced by $\mathrm{S}$. latissima across all treatments (control: $\mathrm{t}=9.083, \mathrm{df}=5, \mathrm{P}=0.0003 ; M$. gigas: $\mathrm{t}=19.188, \mathrm{df}=5, \mathrm{P}<0.001 ;$ M. edulis: $\mathrm{t}=38.0528$, $\mathrm{df}=5, \mathrm{P}<0.001)($ Fig. 2C).

Phosphate levels were significantly enriched by both bivalve treatments from ambient levels of $0.64 \pm 0.11 \mu \mathrm{M}$ in controls to $0.72 \pm 0.12 \mu \mathrm{M}$ in M. gigas and $0.73 \pm 0.14 \mu \mathrm{M}$ in M. edulis treatments (Table 1, Fig. 2D). Phosphate levels were significantly reduced in S. latissima outflow in all treatments, control $(\mathrm{t}=9.893, \mathrm{df}=5, \mathrm{P}<0.001)$, M. gigas $(\mathrm{t}=19.703, \mathrm{df}=5, \mathrm{P}<0.001)$ and M. edulis $(\mathrm{t}=8.193, \mathrm{df}=5$, $\mathrm{P}<0.001)$.

Due to errors in sampling, weeks 8 and 12 were not included in calculations of means during nutrient analysis. Bivalve mortality was seen to be zero after assessment at the end of the experiment.
Table 1 Results of 1-way ANOVA tests to examine variability in (a) nitrite levels, (b) nitrate levels, (c) ammonium levels, (d) phosphate levels, (e) kelp tissue nitrogen, (f) kelp C:N ratio, (g) kelp $\delta^{15} \mathrm{~N}$ content, (h) epiphyte abundance, (i) kelp relative growth rate, (j) total elongation, (k) kelp substantiality index and (1) chlorophyll $a$ levels. Where significant effects were identified by ANOVA, Student-Newman-Keuls (SNK) post hoc tests were used to test pairwise differences

\begin{tabular}{lllll}
\hline Source of variation & $d f$ & $M S$ & $F$ & $P$ \\
\hline (a) Nitrite & & & & \\
Treatment & 2 & 0.52437 & 5.247 & 0.01872 \\
Residual & 15 & 0.09994 & &
\end{tabular}

Pairwise comparison (SNK): M. edulis $>$ Control, $M$. gigas $=$ Control, $M$. edulis $=$ M. gigas

(b) Nitrate

$\begin{array}{lllll}\text { Treatment } & 2 & 0.012601 & 1.0162 & 0.3856\end{array}$

Residual $\quad 15 \quad 0.012399$

(c) Ammonium

$\begin{array}{lllll}\text { Treatment } & 2 & 0.072133 & 17.329 & <0.001\end{array}$

$\begin{array}{lcc}\text { Residual } & 15 & 0.004163\end{array}$

Pairwise comparison (SNK): M. edulis $>$ Control, M. gigas $>$ Control, $M$. edulis $=M$. gigas

(d) Phosphate

$\begin{array}{lllll}\text { Treatment } & 2 & 0.0300029 & 16.154 & <0.001 \\ \text { Residual } & 15 & 0.0018572 & & \end{array}$

Pairwise comparison (SNK): M. edulis $>$ Control, M. gigas $>$ Control, $M$. edulis $=M$. gigas

(e) Kelp tissue nitrogen

$\begin{array}{lllll}\text { Treatment } & 2 & 0.121554 & 12.229 & <0.001 \\ \text { Residual } & 15 & 0.009939 & & \end{array}$

Pairwise comparison $(\mathrm{SNK})$ : $M$. edulis $>$ Control, M. gigas $=$ Control, $M$. edulis $=M$. gigas

(f) Kelp C:N ratio

$\begin{array}{lllll}\text { Treatment } & 2 & 0.5881 & 5.7687 & 0.0137\end{array}$

Residual $\quad 15 \quad 0.10196$

Pairwise comparison (SNK): Control $>$ M. edulis, Control $=M$. gigas, $M$. edulis $=M$. gigas

(g) Kelp $\delta^{15} \mathrm{~N}$ content

$\begin{array}{lllll}\text { Treatment } & 2 & 4.6391 & 5.6458 & 0.0147 \\ \text { Residual } & 15 & 0.8217 & & \end{array}$

Pairwise comparison (SNK): Control $>$ M. edulis, Control $>M$. gigas, $M$. edulis $=$ M. gigas

(h) Epiphyte count

$\begin{array}{lllll}\text { Treatment } & 2 & 18.0469 & 16.492 & <0.001 \\ \text { Residual } & 15 & 1.0943 & & \end{array}$

Pairwise comparison (SNK): Control $>$ M. edulis, Control $>M$. gigas, $M$. edulis $=M$. gigas

(i) Relative growth rate

$\begin{array}{lllll}\text { Treatment } & 2 & 0.013935 & 2.1155 & 0.1415 \\ \text { Residual } & 15 & 0.0065871 & & \\ \text { (j) Elongation } & & & & \\ \text { Treatment } & 2 & 2070.47 & 2.2338 & 0.1551 \\ \text { Residual } & 15 & 926.87 & & \end{array}$

(k) Substantiality index 
Table 1 (continued)

\begin{tabular}{lllll}
\hline Source of variation & $d f$ & $M S$ & $F$ & $P$ \\
\hline Treatment & 2 & 0.20015 & 0.9478 & 0.4096 \\
\hline Residual & 15 & 0.21117 & & \\
$\begin{array}{l}\text { (l) Chlorophyll } a \\
\text { Treatment }\end{array}$ & 2 & 205.3 & 10.777 & $<0.001$ \\
Residual & 176 & 19.05 & & \\
$\begin{array}{l}\text { Pairwise comparison (SNK): Control }>\text { M. edulis, Control }>M . \\
\text { gigas, M. gigas =M. edulis }\end{array}$ & & \\
\hline
\end{tabular}

\section{Chlorophyll a}

Both M. edulis and M. gigas significantly reduced chlorophyll $a$ levels in inflowing water in comparison to control treatments (Table 1, Fig. 3). While M. edulis reduced chlorophyll $a$ levels by $66.6 \%$ and $M$. gigas reduced chlorophyll $a$ by $33.9 \%$, there was no statistically significant difference between bivalve species. While there is trend of stronger biofiltration in M. edulis than in M. gigas, there was a high level of variance between the species prior to $\log$ transformation.

\section{Epiphyte coverage}

Epiphytes, primarily colonial benthic diatoms and to a lesser extent filamentous algae, were present on all individuals of S. latissima, but were not identified to a species level. Counts only include epiphytes that were visible to the naked eye and detectable using image analysis software. As such, coverage of microscopic epiphytes was not assessed. A significant difference in epiphyte coverage between treatments was detected by ANOVA (Table 1). Both M. edulis- and M. gigas-treated seaweeds had fewer epiphytes $(4.2 \pm 0.45$ and $3.8 \pm 0.57$ respectively) than control seaweeds $(6.96 \pm 0.75)$ (individual epiphytes $\mathrm{cm}^{-2} \pm \mathrm{SE}$ ); however, no difference in epiphyte coverage between bivalve treatments was detected (Table 1, Fig. 4).

\section{S. latissima growth and fertile tissue}

There was no significant variation in total elongation, relative growth rate (RGR) or substantiality indices (SI) across treatments (Table 1, Supplementary Fig. 1), with a mean total growth of $327.6 \pm 15 \mathrm{~mm}$, RGR of $5.88 \pm 0.04 \mathrm{~mm} \mathrm{day}^{-1}$ and an SI of $3.9 \pm 0.19 \mathrm{~g}$ wet weight $\mathrm{cm}^{-2}$, in control treatments.
Fig. 2 Concentrations $(\mu \mathrm{M})$ of (A) nitrite $\left(\mathrm{NO}_{2}^{-}\right),($B) nitrate $\left(\mathrm{NO}_{3}^{-}\right),(\mathbf{C})$ ammonium $\left(\mathrm{NH}_{4}^{+}\right)$, and $(\mathbf{D})$ phosphate $\left(\mathrm{PO}_{4}\right)$ in the experimental system. Light grey bars indicate concentrations after bivalve pipes, capital letters indicate significance across the group. Dark grey bars indicate concentrations after seaweed aquaria. Whiskers indicate significance level of filtration of nutrient levels between stages. Error bars indicate SE, $\mathrm{n}=5$
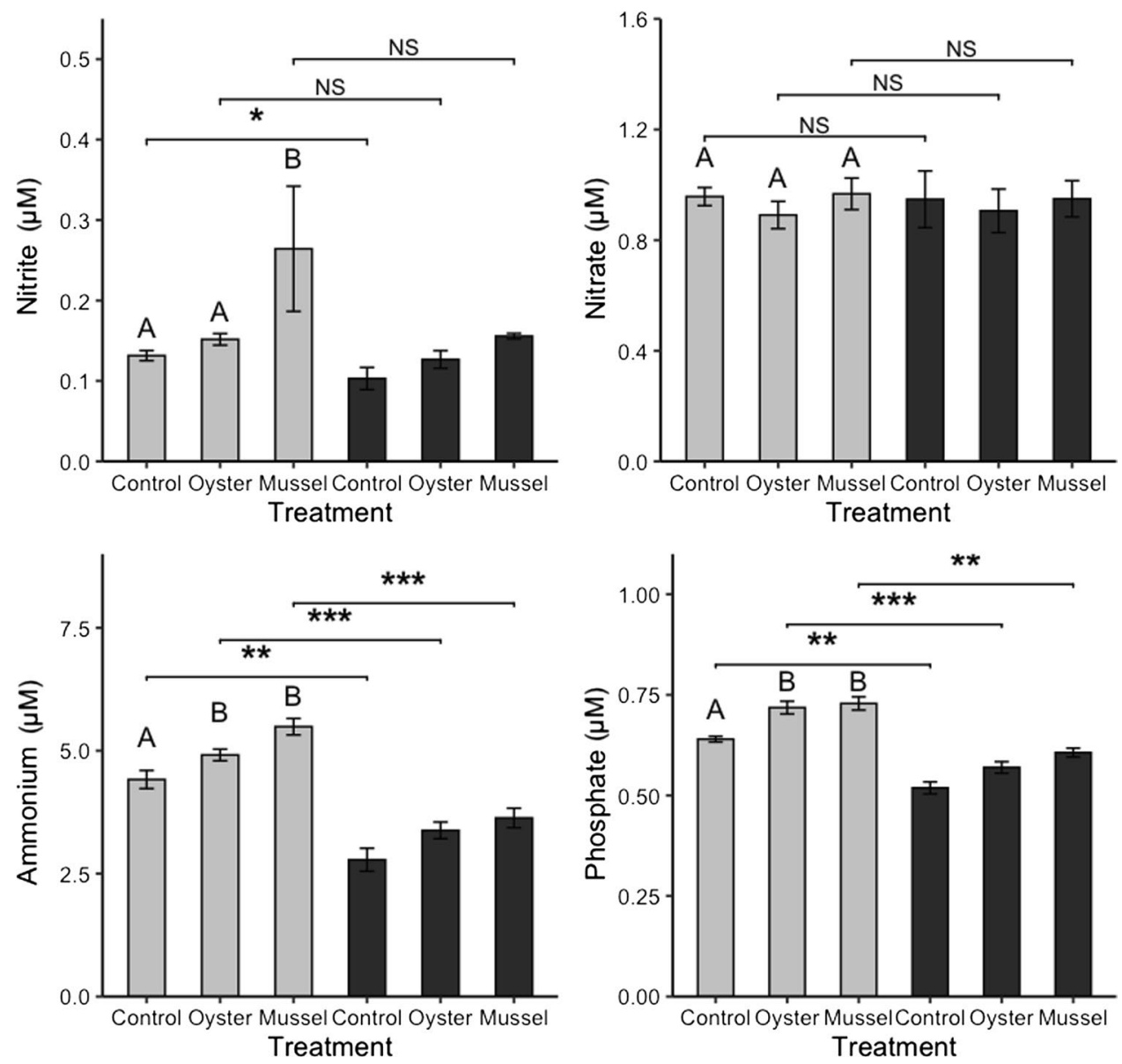


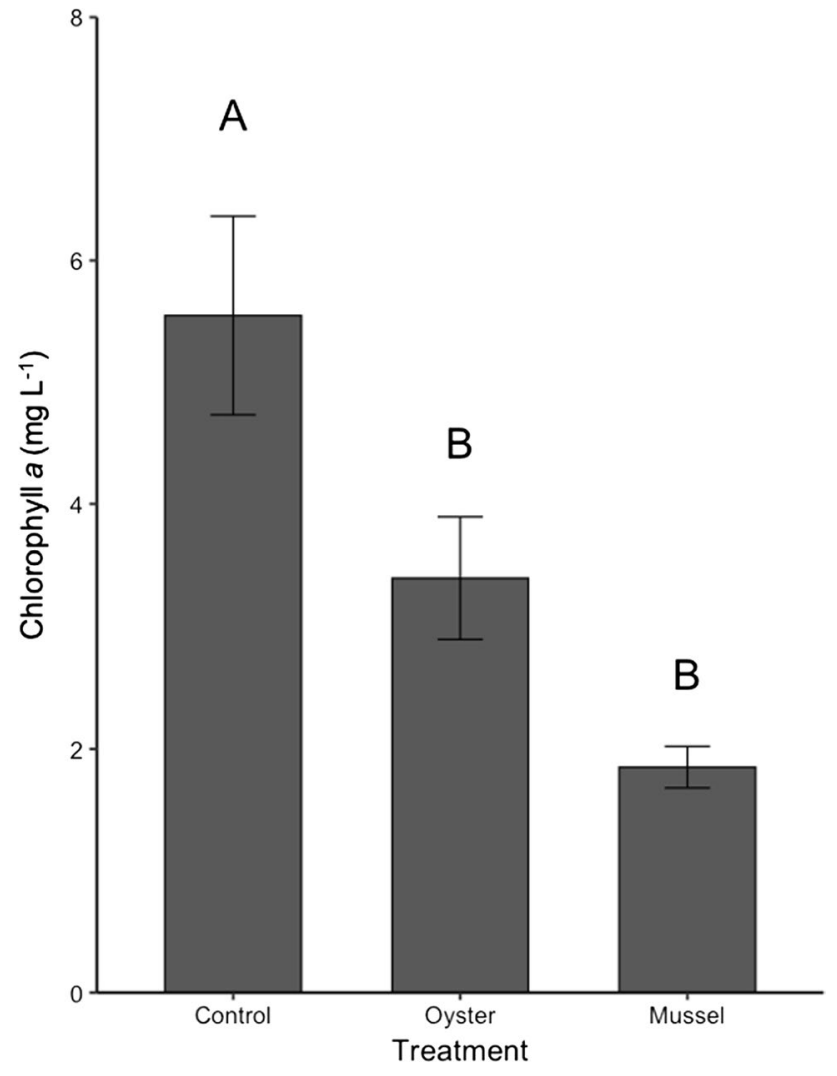

Fig. 3 Chlorophyll $a$ concentration in terms of mg (dry weight) $\mathrm{L}^{-1}$ after the bivalve stage of the experiment. Control treatment indicates ambient seawater untreated by bivalves. Letters indicate significance across treatments. Error bars indicate SE, $n=59$

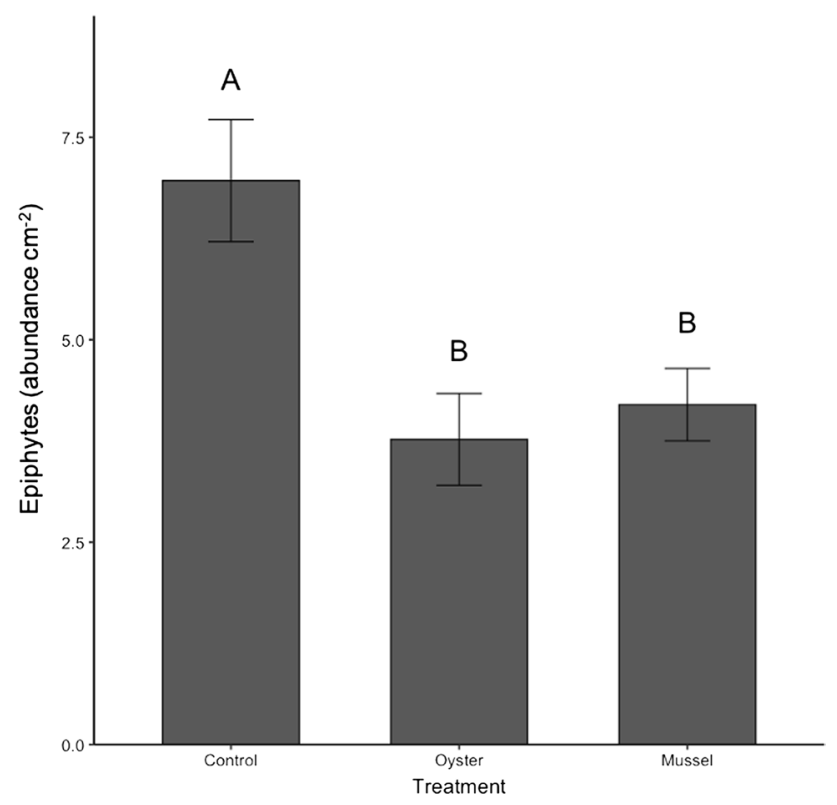

Fig. 4 Epiphyte abundance in terms of number of individual epiphytes per $\mathrm{cm}^{2}$ on apical sections of $S$. latissima. Letters indicate significance across treatments. Error bars indicate SE, $n=5$
The production of fertile $S$. latissima tissue was enhanced in bivalve treatments compared to controls $(\mathrm{H}=8.8, \mathrm{df}=2$, $\mathrm{P}=0.01$ ), with an average of $2.3 \pm 0.5$ individuals having fertile sorus tissue in control treatments compared to $4.5 \pm 1$ and $6 \pm 0.4$ in oyster and mussel treatments respectively (Fig. 5). There was no significant difference in sorus formation between oyster and mussel treatments. Fertile tissue was not present in any individuals at the commencement of the experiment.

\section{Elemental analysis}

The significant nutrient elevations provided by bivalves drove changes in S. latissima tissue content (Table 1, Fig. 6). There was an increase in tissue nitrogen of S. latissima from M. edulis treatments; however, this was not seen in kelp in co-cultivation with $M$. gigas despite significant elevations in ammonium detected in this treatment (Fig. 2A). Concurrently, shifts in C:N ratio were seen in S. latissima from $M$. edulis treatments, driven by the increase in tissue nitrogen. In this case, $\mathrm{C}: \mathrm{N}$ values were reduced in kelps from M. edulis treatments compared to both $M$. gigas and control treatments (Table 1, Fig. 6B). Lastly, variations in nitrogen stable isotope ratios of kelp tissue were detected across treatments. Both M. edulis- and M. gigas-treated kelps had significantly lower $\delta^{15} \mathrm{~N}$ values than control seaweeds, $3.45 \%$ and 3.34 \%o compared to $4.96 \%$, respectively (Table 1, Fig. 6C), indicating an increase in kelp use of ${ }^{14} \mathrm{~N}$ originating from

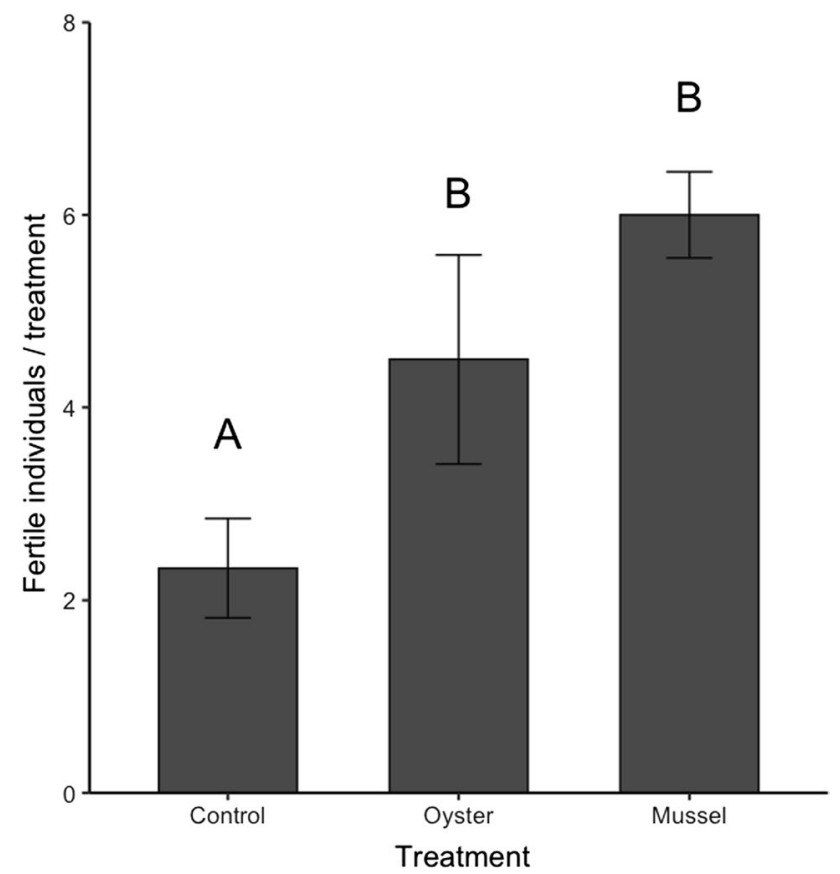

Fig. 5 Number of fertile S. latissima individuals in each treatment at the end of the experimental duration. Letters indicate significance across treatments. Error bars indicate $\mathrm{SE}, \mathrm{n}=5$ 
Fig. 6 S. latissima elemental tissue content of (A) nitrogen, (B) carbon:nitrogen ratio, (C)

${ }^{15} \mathrm{~N}$ value. Letters indicate significance across treatments. Error bars indicate SE, $n=5$
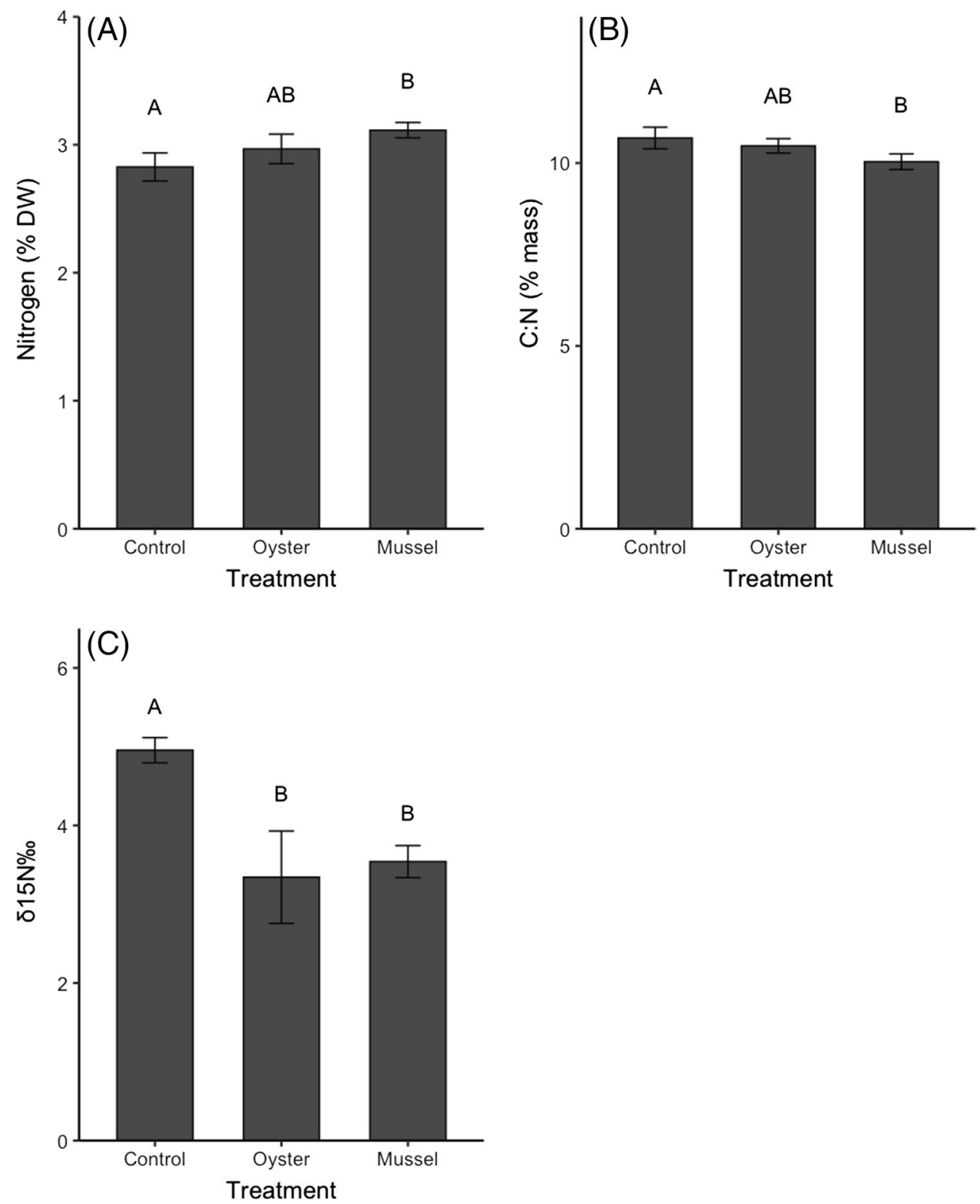

bivalve effluent. Such variation in $\delta^{15} \mathrm{~N}$ between treatments indicates the use of different pools of nitrogen by S. latissima between bivalve and control treatments, where the nitrogen originating from bivalve metabolism was isotopically distinct from the nitrogen in ambient seawater.

\section{Discussion}

Epiphytism is a major problem in seaweed aquaculture, reducing seaweed quality and causing reductions in yields (Vairappan et al., 2008; Park and Hwang 2012). Here, we report a reduction in epiphyte abundance of more than 50\% on kelp tissue using filter feeding bivalves as biofilters in a tank-based cultivation system. Moreover, a positive fertilisation effect of bivalves was seen, where kelps were significantly richer in tissue nitrogen when co-cultivated with M. edulis rather than when cultivated alone, with a tendency for the same trend in treatments with M. gigas. This was most likely due to the enhancement of DIN, primarily ammonium, by the bivalves which was utilised by $S$. latissima. This assertion is supported by the depleted $\delta^{15} \mathrm{~N}$ values in co-cultivated kelp, indicating uptake of DIN originating from bivalves.

Increased nutrient concentrations are usually assumed to result in higher abundances of epiphytes on seaweeds in natural ecosystems (e.g. Rönnberg et al., 1992), particularly opportunistic epiphytic algae on naturally growing fucoid algae around fish farms. In a study of epiphytism on S. latissima and Undaria pinnatifida in Spain, it was suggested that the 
nutrient enrichment by mussel farms may increase the prevalence of epiphytes (Peteiro and Freire 2013). Our results rather indicate a bivalve-driven decline in epiphyte coverage despite elevated nutrient concentrations. The reduction in epiphytes due to bivalve filtration suggests that a controlled co-cultivation, such as a tank-based culture, with mussels may actually contribute to the diminishment of epiphytism on cultivated kelp blades. However, the extent to which these biofouling dynamics may carry over into the field remains to be seen. The implication that the decline in epiphyte coverage is a result of bivalve filtration is supported by the drastic reduction in chlorophyll $a$ in seawater seen after bivalve treatment in comparison to ambient levels from the controls. While removal of other particles such as spores and larvae by the bivalves was not directly investigated, the clearance of chlorophyll $a$ suggests a strong biofiltration capacity of the bivalves in our experiment. The biofiltration capacity of Mytilis sp. is well documented as having a wide size range, from 4 to $1000 \mu \mathrm{m}$ (Davenport et al., 2000; Nielsen and Maar 2007), as well as a high filtration capacity (Møhlenberg and Riisgård 1978; Petersen et al., 2008). As such, the strong reduction of chlorophyll $a$ in this experiment may also indicate the reduction of larger particles, such as larval stages of potential biofouling species. The clearance rates seen in the experiment $(66.6 \%$ and $33.9 \%$ for mussels and oysters, respectively) fall short of the maximal $80 \%$ previously reported (Petersen et al., 2008). Still, these values represent a major reduction in phytoplankton passing through to seaweed tanks, and apparently drove a reduction in epiphyte coverage by benthic diatoms on kelp blades. In a recent review paper (Bannister et al., 2019) summarising the impacts and current mitigation techniques for biofouling in aquaculture biological, several means of controlling epiphytes were considered; however, to our knowledge, the utilisation of filter feeding bivalves as biofilters in aquaculture has to date not been explored.

Despite the significant increases in bioavailable DIN and DIP provided by bivalve treatments, we did not observe any significant alterations to $S$. latissima growth. This is contrary to the body of literature describing kelp growth dynamics when implemented in an IMTA system, where kelps are frequently seen to increase in growth. For example, in an IMTA system where $S$. latissima was grown alongside salmon farms in Canada, kelp growth was increased by $46 \%$ (Chopin and Bastarache 2004). However, it is difficult to draw direct comparisons between the kelp growth in our system and an intensive finfish cultivation, as nitrogen effluents from fish farms can be great. In our study, the mean ammonium elevation by $M$. edulis treatments was $1.1 \mu \mathrm{M}$ and the maximum observed elevation was $6.1 \mu \mathrm{M}$ above ambient levels, whereas finfish cultivations have been seen to elevate ammonium by as much as $34 \mu \mathrm{M}$ (Ahn et al., 1998). The absence of an increased growth rate in kelps co-cultivated with bivalves in our study, despite significant ammonium elevations, may indicate that ambient nitrogen levels in control treatments were sufficiently high and were not limiting for kelp growth. Although we did not detect variation in kelp growth, we did observe small but significant alterations to the elemental composition of S. latissima across treatments, as well as a concurrent decline in C:N. However, our observed increases in tissue nitrogen of $0.2 \%$ fall short of the $1 \%$ increase observed by Handå et al., (2013), but once again, drawing parallels between our cultivation system and a field-sized cultivation may be unreasonable. While observed increases in tissue nitrogen can be small, they result in greater alterations in protein content. For example, a nitrogen-to-protein conversion factor of 4.37 has been presented for S. latissima (Biancarosa et al., 2017), which implies a $13.6 \%$ protein content of kelps grown in combination with $M$. edulis in our study, compared to $12.2 \%$ in control treatments.

The findings with regard to dissolved nutrient production by the bivalves in our system are largely supported by the body of literature to date. Nutrient elevation by filter feeding bivalves in both natural and cultivation settings has been widely reported (Dame 1993; Newell 2004; Jansen et al., 2011). In our study, a relatively small aggregation, 32 individuals, was seen to significantly enhanced DIN over a 12-week period. As expected, ammonium was the most elevated nitrogen species by bivalves. Since the conversion of ammonium to nitrite and nitrate is bacterially mediated (Ward 1996), it is unlikely that nitrification occurred within our system due to rapid flowrates and flushing of the system. As such, detected levels of nitrite and nitrate most likely originated from ambient seawater. We also detected minor but statistically significant elevations of DIP by both bivalve species in our system. DIP concentrations have been seen to be enhanced by up to $5 \%$ by M. edulis (compared to $20 \%$ DIN enhancement) during the summer (Jansen et al., 2011); however, in our study, we observed a $13.8 \%$ increase in phosphate in M. edulis effluents in comparison to control treatments.

The significant reduction of ammonium between bivalve and seaweed tanks as well as the lack of uptake of nitrate by $S$. latissima, despite consistent bioavailable concentrations, suggests a preference of ammonium as a nitrogen source. Previously, S. latissima has been reported to display simultaneous uptake of both nitrate and ammonium when both forms are supplied (Harrison et al., 1986). In our study, ammonium was available on average at a fivefold higher concentration than nitrate, which suggests a sufficient supply of nitrogen was available as ammonium.

Interestingly, by taking the mean $\mathrm{NH}_{4}{ }^{+}$and $\mathrm{PO}_{4}{ }^{3-}$ concentrations from mussel treatments $(5.5$ and $0.73 \mu \mathrm{M}$, respectively) and subtracting the concurrent $\mathrm{NH}_{4}{ }^{+}$and $\mathrm{PO}_{4}{ }^{3-}$ concentrations after nutrient uptake by the seaweeds (3.7 and 
$0.60 \mu \mathrm{M}$, respectively) to obtain a rough estimate of seaweed nutrient uptake, we find an $\mathrm{N}: \mathrm{P}$ uptake ratio of $15: 1$. This value falls within the range of values reported for the $\mathrm{N}: \mathrm{P}$ for other kelps (Atkinson and Smith 1983), as well as close to the original N:P value reported by Redfield (1958) of 16:1. The lack of deviance from previously reported values for optimal N:P values indicates that kelps were limited by neither $\mathrm{NH}_{4}{ }^{+}$nor $\mathrm{PO}_{4}{ }^{3-}$ in mussel treatments. However, in the case of the control treatment, an uptake N:P of 13.53 was seen, indicating that nitrogen availability was sub-optimum in control treatments. Thus, it appears that the slight $\mathrm{NH}_{4}{ }^{+}$ enrichment provided by $M$. edulis gives a fertilisation effect upon the kelp, resulting in increases of stored nitrogen in kelps, via a more optimal DIN:DIP availability.

This differential bioavailability of DIN due to bivalve $\mathrm{NH}_{4}{ }^{+}$release and its concurrent assimilation into kelp tissue is visible through the stable isotope data. The more depleted $\delta^{15} \mathrm{~N}$ values in seaweed supplied with effluent from M. edulis and $M$. gigas in comparison to control kelps indicates distinct DIN pool use between bivalve and control groups. In this case, it appears that the ambient seawater was enriched in $\delta^{15} \mathrm{~N}$, whereas the effluents from bivalves were relatively depleted. The preferential use of more depleted $\delta^{15} \mathrm{~N}$ substrates by organisms is a core concept in stable isotope ecology (Fry 2006). In this study, it appears the bivalve effluent was less enriched in heavy nitrogen and therefore was preferentially used over the 'heavier' $\mathrm{NH}_{4}{ }^{+}$in ambient water.

Finally, and beyond the scope of our expectations, we observed the earlier development of fertile tissue in S. latissima individuals co-cultured with bivalves. Previously, it has been suggested that sorus formation in S. latissima is based on photoperiod, stimulated by short day lengths (Lüning and Freshwater 1988). Such short days were the case at the end of our experiment in early November; however, it is likely that the disparity in sorus formation seen across our treatments is due to DIN availability. Sorus formation has been seen to be delayed in S. latissima due to insufficient levels of tissue nitrogen (Nimura et al., 2002). Based on our rough estimates of $\mathrm{N}: \mathrm{P}$ uptake across our treatments, it appears the kelps in control treatments displayed suboptimal N:P dynamics, which may contribute to explaining the observed phenomenon of differential sorus formation across treatments.

To conclude, our research describes a multi-trophic aquaculture system in which filter feeding bivalves confer a biofiltration and fertilisation effect upon our target species for cultivation, Saccharina latissima, in tank culture. By designing a system in which all seawater provided to $S$. latissima was available for filtration by bivalves, we observed enhanced dissolved inorganic nitrogen and a reduction in chlorophyll $a$ after the bivalve stage, and a decline in seaweed biofouling as well as enhanced biomass value due to alterations in elemental tissue composition. These valuable alterations were achieved without the use of mechanical filters or externally supplied nutrients. While we observed strong fertilisation and biofiltration effects in mesocosm, the potential for integrating filter feeding bivalve and macroalgal cultivation in field scale cultivations remains largely unexplored. Integrating these species in open sea cultivations will introduce factors such as local hydrodynamics and nutrient attenuation which may dampen or accentuate the trends observed in this study.

Supplementary Information The online version contains supplementary material available at https://doi.org/10.1007/s10811-021-02553-6.

Acknowledgements We wish to thank Gunnar Cervin for assistance in designing and constructing the experimental system and Hans Olsson for water nutrient analysis. This work was conducted as part of the Swedish Mariculture Research Centre (SWEMARC), Centre for Sea and Society, University of Gothenburg.

Funding Open access funding provided by University of Gothenburg. This study was funded by SWEMARC Swedish Mariculture Research Centre (SWEMARC), Centre for Sea and Society, University of Gothenburg.

Data availability Data are available under request to the authors.

\section{Declarations}

Conflict of interest The authors declare no competing interests.

Open Access This article is licensed under a Creative Commons Attribution 4.0 International License, which permits use, sharing, adaptation, distribution and reproduction in any medium or format, as long as you give appropriate credit to the original author(s) and the source, provide a link to the Creative Commons licence, and indicate if changes were made. The images or other third party material in this article are included in the article's Creative Commons licence, unless indicated otherwise in a credit line to the material. If material is not included in the article's Creative Commons licence and your intended use is not permitted by statutory regulation or exceeds the permitted use, you will need to obtain permission directly from the copyright holder. To view a copy of this licence, visit http://creativecommons.org/licenses/by/4.0/.

\section{References}

Ahn O, Petrell R, Harrison P (1998) Ammonium and nitrate uptake by Laminaria saccharina and Nereocystis luetkeana originating from a salmon sea cage farm. J Appl Phycol 10:333-340

Ajjabi CL, Abaab M, Segni R (2018) The red macroalga Gracilaria verrucosa in co-culture with the Mediterranean mussels Mytilus galloprovincialis: productivity and nutrient removal performance. Aquac Int 26:253-266

Aquilino KM, Bracken MES, Faubel MN, Stachowicz JJ (2009) Localscale nutrient regeneration facilitates seaweed growth on waveexposed rocky shores in an upwelling system. Limnol Oceanogr 54:309-317

Atkinson MJ, Smith S (1983) C : N : P ratios of benthic marine. Limnol Oceanogr 28:568-574 
Aure J, Strohmeier T, Strand Ø (2007) Modelling current speed and carrying capacity in long-line blue mussel (Mytilus edulis) farms. Aquac Res 38:304-312

Ballantine DL (1979) The distrubution of algal epiphytes on macrophyte hosts offshore from La Parguera, Puerto Rico. Bot Mar 22:107-111

Bannister J, Sievers M, Bush F, Bloecher N (2019) Biofouling in marine aquaculture: a review of recent research and developments. Biofouling 35:631-648

Biancarosa I, Espe M, Bruckner CG, Heesch S, Liland N, Waagb $\varnothing$ R, Torstensen B, Lock EJ (2017) Amino acid composition, protein content, and nitrogen-to-protein conversion factors of 21 seaweed species from Norwegian waters. J Appl Phycol 29:1001-1009

Boyd CE (1979) Water quality in warmwater fish ponds. Agricultural Experimental Station, Auburn University

Buschmann AH, Correa J, Westermeier R, Hernández-González MDC (2001) Red algal farming in Chile: a review. Aquaculture 194:203-220

Chapman ARO, Craigie JS (1977) Seasonal growth in Laminaria longicruris: relations with dissolved inorganic nutrients and internal reserves of nitrogen. Mar Biol 40:197-205

Chopin T, Bastarache S (2004) Mariculture in Canada: finfish, shellfish and seaweed. World Aquac Sept 2004, pp 37-41

Chopin T, Buschmann AH, Halling C, Troell M, Kautsky N, Neori A, Kraemer GP, Zertuche-González JA, Yarish C, Neefus C (2001) Integrating seaweeds into marine aquaculture systems: a key toward sustainability. J Phycol 37:975-986

Cranford PJ, Duarte P, Robinson SM, Fernández-Reiriz MJ, Labarta U (2014) Suspended particulate matter depletion and flow modification inside mussel (Mytilus galloprovincialis) culture rafts in the Ría de Betanzos, Spain. J Exp Mar Biol Ecol 452:70-81

Dame R (1993) The role of bivalve filter feeder material fluxes in estuarine ecosystems. In: Dame RF (ed) Bivalve filter feeders in estuarine and coastal processes. Springer, Berlin, pp 245-269

Dame R, Spurrier J, Wolaver T (1989) Carbon, nitrogen and phosphorus processing by an oyster reef. Mar Ecol Prog Ser 54:249-256

Dame RF, Dankers N (1988) Uptake and release of materials by a Wadden sea mussel bed. J Exp Mar Bio Ecol 118:207-216

Davenport J, Smith RJJW, Packer M (2000) Mussels Mytilus edulis: significant consumers and destroyers of mesozooplankton. Mar Ecol Prog Ser 198:131-137

Dean PR (1998) The nutrient and photosynthetic eco-physiology of Undaria pinnatifida, with applications to aquaculture. MSc Thesis, University of Otago

Dürr S, Watson DI (2010) Biofouling and antifouling in aquaculture. Biofouling 12:267-287

Edding M, Macchiavello J, Black H (1987) Culture of Gracilaria sp. in outdoor tanks: productivity. In: Ragan MA, Bird CJ (eds) Twelfth International Seaweed Symposium. Kluwer, Dordrecht, pp 369-373

Freitas JRC, Manuel J, Morrondo S (2016) Saccharina latissima (Laminariales, Ochrophyta) farming in an industrial IMTA system in Galicia (Spain). J Appl Phycol 28:377-385

Friedlander M (1992) Gracilaria conferta and its epiphytes: the effect of culture conditions on growth. Bot Mar 35:423-428

Fry B (2006) Stable Isotope Ecology. Springer, NY

Gledhill M, Brown MT, Nimmo M, Moate R, Hill SJ (1998) Comparison of techniques for the removal of particulate material from seaweed tissue. Mar Environ Res 45:295-307

Grant J, Bacher C, Cranford PJ, Guyondet T, Carreau M (2008) A spatially explicit ecosystem model of seston depletion in dense mussel culture. J Mar Syst 73:155-168
Haglund KA (1994) Photosynthesis and growth of some marine algae, with emphasis on the rhodophyte Gracilaria tenuistipitata. Thesis, Uppsala University

Haines KC (1975) Growth of the carrageenan-producing tropical red seaweed Hypnea musciformis in surface water, $870 \mathrm{~m}$ deep water, effluent from a clam mariculture system, and in deep water enriched with artificial fertilizers or domestic sewage. In: Persoone G, Jaspers E (eds) Proceedings of the 10th European Symposium on Marine Biology, Ostend, Belgium, Sept. 17-23, 1975: 1. Research in mariculture at laboratory- and pilot scale. IZWO, Wetteren pp 207-220

Handå A, Forbord S, Wang X, Broch OJ, Dahle SW, Størseth TR, Reitan KI, Olsen Y, Skjermo J (2013) Seasonal- and depthdependent growth of cultivated kelp (Saccharina latissima) in close proximity to salmon (Salmo salar) aquaculture in Norway. Aquaculture 414-415:191-201

Harrison PJ, Druehl LD, Lloyd KE, Thompson PA (1986) Nitrogen uptake kinetics in three year-classes of Laminaria groenlandica (Laminariales: Phaeophyta). Mar Biol 93:29-35

Harrison PJ, Hurd CL (2001) Nutrient physiology of seaweeds: application of concepts to aquaculture. Cah Biol Mar 42:71-82

Hurtado AQ, Critchley AT, Trespoey A, Lhonneur GB (2006) Occurrence of Polysiphonia epiphytes in Kappaphycus farms at Calaguas Is., Camarines Norte, Phillippines. J Appl Phycol 18:301-306

Jansen HM (2012) Bivalve nutrient cycling: nutrient turnover by suspended mussel communities in oligotrophic fjords. PhD Thesis, Wageningen University

Jansen HM, Strand Ø, Strohmeier T, Krogness C, Verdegem M, Smaal A (2011) Seasonal variability in nutrient regeneration by mussel Mytilus edulis rope culture in oligotrophic systems. Mar Ecol Prog Ser 431:137-149

Kim JK, Yarish C, Hwang EK, Park M, Kim Y (2017) Seaweed aquaculture: cultivation technologies, challenges and its ecosystem services. Algae 32:1-13

Langton RW, Haines KC, Lyon RE (1977) Ammonia-nitrogen production by the bivalve mollusc Tapes japonica and its recovery by the red seaweed Hypnea musciformis in a tropical mariculture system. Helgol Wissensch Meeresunters 30:217-229

Lignell Å, Pedersén M (1989) Agar composition as a function of morphology and growth rate. Studies on some morphological strains of Gracilaria secundata and Gracilaria verrucosa (Rhodophyta). Bot Mar 32:219-228

Lindahl O, Hart R, Hernroth B, Kollberg S, Loo LO, Olrog L, Rehnstam-Holm AS, Svensson J, Svensson S, Syversen U (2005) Improving marine water quality by mussel farming: a profitable solution for Swedish society. AMBIO 34:131-138

Lüning K, Freshwater W (1988) Temperature tolerance of Northeast Pacific marine algae. J Phycol 24:310-315

Mao Y, Yang H, Zhou Y, Ye N, Fang J (2009) Potential of the seaweed Gracilaria lemaneiformis for integrated multi-trophic aquaculture with scallop Chlamys farreri in North China. J Appl Phycol 21:649-656

Møhlenberg F, Riisgård HU (1978) Efficiency of particle retention in 13 species of suspension feeding bivalves. Ophelia 17:239-246

Newell RIE (2004) Ecosystem influences of natural and cultivated populations of suspension-feeding bivalve molluscs: a review. J Shellfish Res 23:51-61

Nielsen TG, Maar M (2007) Effects of a blue mussel Mytilus edulis bed on vertical distribution and composition of the pelagic food web. Mar Ecol Prog Ser 339:185-198

Nimura K, Mizuta H, Yamamoto H (2002) Critical contents of nitrogen and phosphorus for sorus formation in four Laminaria species. Bot Mar 45:184-188 
Ogawa H, Fujita M (1997) The effect of fertilizer application on farming of the seaweed Undaria pinnatifida (Laminariales, Phaeophyta). Phycol Res 45:113-116

Park CS, Hwang EK (2012) Seasonality of epiphytic development of the hydroid Obelia geniculata on cultivated Saccharina japonica (Laminariaceae, Phaeophyta) in Korea. J Appl Phycol 24:433-439

Parke M (1948) Laminaria ochroleuca de la Pylaie growing on the coast of Britain. Nature 162:295-296

Peteiro C, Freire O (2013) Epiphytism on blades of the edible kelps Undaria pinnatifida and Saccharina latissima farmed under different abiotic conditions. J World Aquac Soc 44:706-715

Petersen JK, Nielsen TG, van Duren L, Maar M (2008) Depletion of plankton in a raft culture of Mytilusgalloprovincialis in Ría de Vigo NW Spain. I. Phytoplankton. Aquat Biol 4:113-125

Pickering TD, Gordon ME, Tong LJ (1993) Effect of nutrient pulse concentration and frequency on growth of Gracilaria chilensis plants and levels of epiphytic algae. J Appl Phycol 5:525-533

Redfield AC (1958) The biological control of chemical factors in the environment. Am Sci 46:230A, 205-221

Rolin C, Inkster R, Laing J, McEvoy L (2017) Regrowth and biofouling in two species of cultivated kelp in the Shetland Islands, UK. J Appl Phycol 29:2351-2361

Rönnberg O, Ådjers K, Ruokolahti C, Bondestam M (1992) Effects of fish farming on growth, epiphytes and nutrient content of Fucus vesiculosus $\mathrm{L}$. in the Aland archipelago, northern Baltic Sea. Aquat Bot 42:109-120

Rueness J, Fredriksen S (1989) Culture studies of agarophytes with special reference to Gelidium species at their northern limit of distribution. Outdoor Seaweed Cultiv Proc Second Work COST 48:55-58

Shacklock PF, Doyle RW (1983) Control of epiphytes in seaweed cultures using grazers. Aquaculture 31:141-151

Smit AJ, Fourie AM, Robertson BL, Du Preez DR (2003) Control of the herbivorous isopod, Paridotea reticulata, in Gracilaria gracilis tank cultures. Aquaculture 217:385-393
Soto D (ed) (2009) Integrated mariculture: a global review. FAO Fisheries and Aquaculture Technical Paper 529, FAO, Rome

Taylor MW, Rees TAV (1999) Kinetics of ammonium assimilation in two seaweeds, Enteromorpha sp. (Chlorophyceae) and Osmundaria colensoi (Rhodophyceae). J Phycol 746:740-746

Troell M, Halling C, Nilsson A, Buschmann AH, Kautsky N, Kautsky L (1997) Integrated marine cultivation of Gracilaria chilensis (Gracilariales, Rhodophyta) and salmon cages for reduced environmental impact and increased economic output. Aquaculture $156: 45-61$

Troost K (2010) Causes and effects of a highly successful marine invasion: case-study of the introduced Pacific oyster Crassostrea gigas in continental NW European estuaries. J Sea Res 64:145-165

Ugarte R, Santelices B (1992) Experimental tank cultivation of Gracilaria chilensis in central Chile. Aquaculture 101:7-16

Vairappan CS, Chung CS, Hurtado AQ, Soya FE, Lhonneur GB, Critchley A (2008) Distribution and symptoms of epiphyte infection in major carrageenophyte-producing farms. J Appl Phycol 20:477-483

Veeragurunathan V, Eswaran K, Malarvizhi J, Gobalakrishnan M (2015) Cultivation of Gracilaria dura in the open sea along the southeast coast of India. J Appl Phycol 27:2353-2365

Ward BB (1996) Nitrification and denitrification: probing the nitrogen cycle in aquatic environments. Microb Ecol 32:247-261

Wheeler PA, North WJ (1981) Nitrogen supply, tissue composition and frond growth rates for Macrocystis pyrifera off the coast of southern California. Mar Biol 64:59-69

Wildish DJ, Miyares MP (1990) Filtration rate of blue mussels as a function of flow velocity: preliminary experiments. J Exp Mar Biol Ecol 142:213-219

Publisher's note Springer Nature remains neutral with regard to jurisdictional claims in published maps and institutional affiliations. 